\title{
Highly Efficient and Enantiomer-Selective Hydrolysis of $\alpha$-Amino Acid Active Ester Hydrochlorides by a Cyclic Hexapeptide Containing Histidines
}

\author{
Masao TANIHARA and Yukio IMANISHI \\ Department of Polymer Chemistry, Kyoto University, \\ Honmachi, Yoshida, Sakyo-ku, Kyoto 606, Japan
}

(Received September 22, 1982)

\begin{abstract}
A cyclic hexapeptide, cyclo(D-Leu-L-Glu-L-His) ${ }_{2}$ was synthesized and its catalytic activity for the hydrolysis of various carboxylic acid $p$-nitrophenyl esters was investigated. Cyclo(D-Leu-L-Glu-L-His) $)_{2}$ was 3 to 20 times as effective as imidazole as a catalyst for the hydrolysis of $\mathrm{CH}_{3}\left(\mathrm{CH}_{2}\right)_{8} \mathrm{COOPh}\left(\mathrm{NO}_{2}\right)$ and $\mathrm{CH}_{3}\left(\mathrm{CH}_{2}\right)_{10} \mathrm{COOPh}\left(\mathrm{NO}_{2}\right)$ in $20 \%$ dioxane $/ \mathrm{H}_{2} \mathrm{O}$ mixture at $\mathrm{pH} 7.8$ (phosphate buffer). Cyclo(D-Leu-L-Glu-L-His) ${ }_{2}$ showed neither higher catalytic activity than imidazole nor enantiomer-selective catalysis in the hydrolysis of $\mathrm{Val}-\mathrm{OPh}\left(\mathrm{NO}_{2}\right) \cdot \mathrm{HCl}$ and $\mathrm{Leu}-\mathrm{OPh}\left(\mathrm{NO}_{2}\right) \cdot \mathrm{HCl}$ in aqueous solution at $\mathrm{pH} 6.95$ (phosphate buffer). When $\mathrm{Cu}\left(\mathrm{ClO}_{4}\right)_{2}$ was added to an aqueous solution of cyclo(D-Leu-L-Glu-L-His) ${ }_{2}$ at pH 6.05 (phosphate buffer), a 40 150 time increase in the second-order rate constant of both the above $\alpha$-amino acid active ester hydrochlorides was observed and the L-enantiomers were hydrolyzed slightly faster than the Denantiomers. The addition of $\mathrm{Cu}\left(\mathrm{ClO}_{4}\right)_{2}$ to an aqueous solution containing the cyclic hexapeptide at $\mathrm{pH} 6.01$ (citrate buffer) did not lead to peptide-metal ion interaction and an enhanced rate of enantiomer-selective hydrolysis. It was made clear that cyclo(D-Leu-L-Glu-L-His) ${ }_{2}$ is a highly efficient and weakly enantiomer-selective catalyst in the hydrolysis of $\alpha$-amino acid active ester hydrochlorides only when it forms a complex with copper ion.

KEY WORDS Cyclic Hexapeptide / Hydrolytic Catalyst / Hydrophobic Interaction / Enantiomer-Selective Catalysis / $\mathrm{Cu}^{2+}-$ Peptide Complex /
\end{abstract}

We investigated the construction of an efficient and specific hydrolytic catalyst by controlling the spatial arrangement, that is, the intramolecular cooperation, of functional groups by incorporating them into the side chains of a relatively rigid cyclic peptide.

Cyclic dipeptides consisting of $\alpha$-amino acid residues having hydrophobic and nucleophilic side chains have been found efficient catalysts for the hydrolyses of $p$-nitrophenyl esters of long-chain carboxylic acids ${ }^{1,2}$ and $p$-nitrophenyl ester hydrochlorides of hydrophobic $\alpha$-amino acids. ${ }^{3}$ Cyclic dipeptides having the D-L configuration were more efficient as hydrolytic catalysts than imidazole and diastereomeric dipeptides having the L-L configuration. These findings have been discussed in terms of the effect of the spatial arrangement of functional groups on the hydrophobic binding of a substrate and intramolecular nucleophilic or general-base catalysis. ${ }^{3,4}$

Cyclic dipeptides consisting of $\alpha$-amino acid residues having anionic and nucleophilic side chains have been found efficient catalysts for the hydrolyses of positively charged carboxylic acid esters and $p$-nitrophenyl ester hydrochlorides of $\alpha$-amino acids. ${ }^{5}$ Cyclic dipeptides having the L-L configuration were more efficient as hydrolytic catalysts than imidazole which is more basic and the diastereomeric cyclic dipeptides having the D-L configuration. These findings have been discussed in terms of the effect of the spatial arrangement of functional groups on the electrostatic binding of a substrate and an intramolecular nucleophilic or a generalbase catalysis. $^{5}$

A series of cyclic dipeptide catalysts have been found efficient as catalysts for the hydrolysis of $\alpha$ amino acid active ester hydrochlorides under suitable conditions, but an enantiomer-selective catalysis 
has yet to be discovered. As one possible way for obtaining an enantiomer-selective catalysis, the introduction of an additional steric barrier into cyclic dipeptide was considered and tripeptides having cyclic dipeptide backbone were constructed. ${ }^{6}$ These tripeptide catalysts were enantiomer-selective in the hydrolysis of $p$-nitrophenyl leucinate hydrochloride, and the selectivity for the D-ester was induced by a conformational change of the tripeptide catalysts on binding of the D-ester resulting in enhanced catalysis. $^{7}$

In the present investigation, as an alternative means for constructing an enantiomer-selective catalyst, the ring expansion of cyclic peptide catalysts was considered. A cyclic hexapeptide consisting of hydrophobic and anionic $\alpha$-amino acids as well as nucleophilic histidine was synthesized. Using this cyclic hexapeptide as a hydrolytic catalyst for long-chain carboxylic acid esters and $\alpha$ amino acid active ester hydrochlorides, the stereochemistry participating in substrate binding and intramolecular cooperative catalysis was investigated.

\section{EXPERIMENTAL}

\section{Catalyst}

The cyclic hexapeptide used in the present investigation was cyclo(D-Leu-L-Glu-L-His) ${ }_{2}$. In this cyclic hexapeptide, hydrophobic $\alpha$-amino acid residues (Leu) and nucleophilic $\alpha$-amino acid residues (His) are in a D-L sequence which has been found effective for the hydrolysis of hydrophobic substrate. ${ }^{1,2}$ Anionic $\alpha$-amino acid residues (Glu) and nucleophilic $\alpha$-amino acid residues (His) are in an $\mathrm{L}^{-}$ $\mathrm{L}$ sequence which has been found effective for the hydrolysis of cationic substrate. ${ }^{5}$ The synthesis of the cyclic hexapeptide is illustrated in Figure 1.

$N$ - $t$-Butyloxycarbonyl- $\gamma$-benzyl-L-glutamic Acid Succinimide Ester [Boc-L-Glu(OBzl)-OSu] (I). This was synthesized from L-glutamic acid according to the literature. ${ }^{8}$ Yield $c a .30 \% ; \mathrm{mp} 102^{\circ} \mathrm{C}$ [lit. $^{8}$ $\left.101^{\circ} \mathrm{C}\right]$.

L-Histidine Methyl Ester Dihydrochloride (L-His$\mathrm{OMe} \cdot 2 \mathrm{HCl}$ ) (II). This was synthesized from Lhistidine according to the literature. ${ }^{9}$ Yield $c a .85 \%$; mp $203^{\circ} \mathrm{C}$ [lit. $.^{9} 200-201^{\circ} \mathrm{C}$.

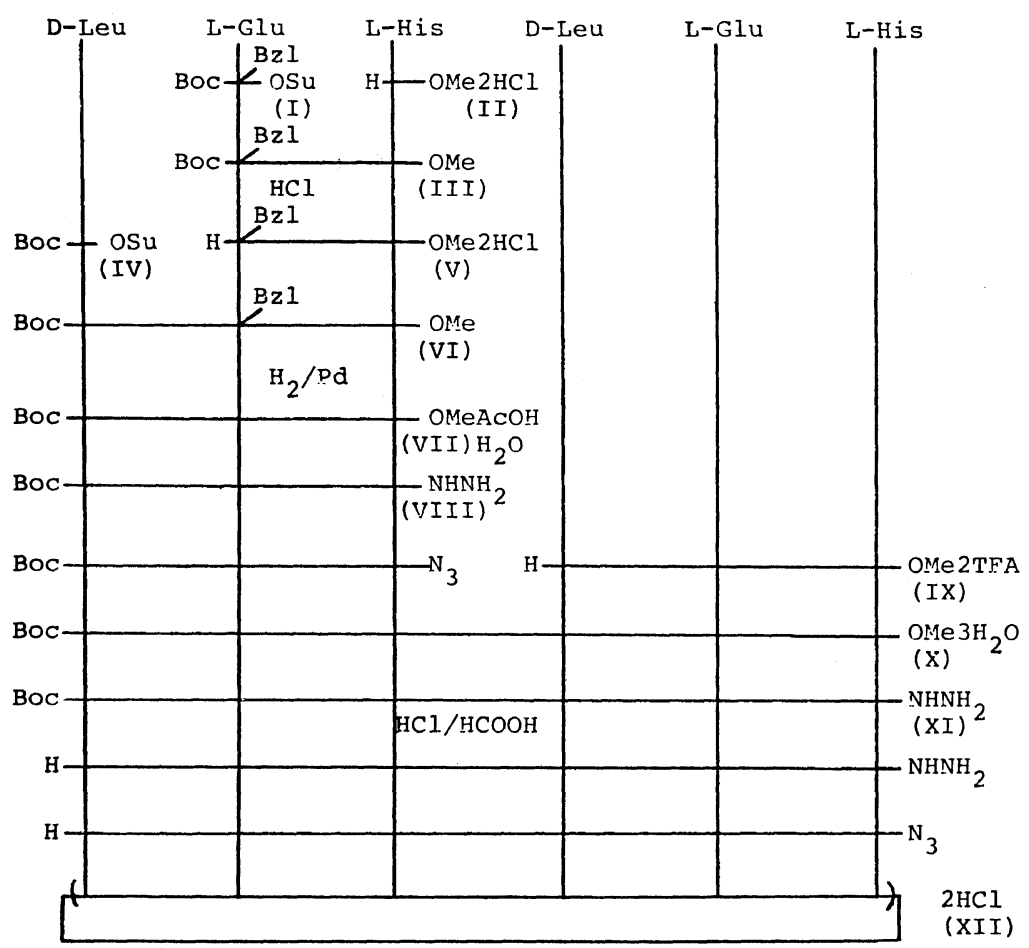

Figure 1. Synthetic route to cyclo(D-Leu-L-Glu-L-His) $)_{2}$. 
$N$-t-Butyloxycarbonyl- $\gamma$-benzyl-L-glutamyl-Lhistidine Methyl Ester [Boc-L-Glu(OBzl)-L-His$\mathrm{OMe}$ (III). $\mathrm{Et}_{3} \mathrm{~N}\left(5.4 \mathrm{~cm}^{3}, 0.04 \mathrm{~mol}\right)$ and $\mathbf{I}(8.70 \mathrm{~g}$, $0.02 \mathrm{~mol})$ were added to a solution of II $(4.84 \mathrm{~g}$, $0.02 \mathrm{~mol})$ in $\mathrm{CH}_{2} \mathrm{Cl}_{2}$ at $0^{\circ} \mathrm{C}$. After standing overnight at room temperature, the solution was evaporated to dryness. AcOEt was added to the residue and the insoluble part (mainly $\mathrm{Et}_{3} \mathrm{~N}^{+} \mathrm{HCl}^{-}$) was filtered off. The AcOEt solution was washed with water, $0.5 \mathrm{~mol} \mathrm{dm}^{-3}$ aqueous $\mathrm{NaHCO}_{3}$ solution, $0.3 \mathrm{~mol} \mathrm{dm}^{-3}$ aqueous citric acid solution, and saturated aqueous solution of $\mathrm{NaCl}$. The AcOEt solution was dried over anhydrous $\mathrm{Na}_{2} \mathrm{SO}_{4}$ and AcOEt was distilled off. To the residual oil, $\mathrm{Et}_{2} \mathrm{O}$ was added and the solidified product was recrystallized from $\mathrm{EtOH} / \mathrm{AcOEt} / \mathrm{Et}_{2} \mathrm{O}$. Yield $7.07 \mathrm{~g} \mathrm{(72 \% )}$; $\mathrm{mp} 69^{\circ} \mathrm{C}$.

$N$-t-Butyloxycarbonyl-D-leucine Succinimide Ester (Boc-D-Leu-OSu) (IV). This was synthesized from D-leucine according to the literature ${ }^{10}$ which describes the synthesis of Boc-L-Leu-OSu. Yield $72 \%$; $\mathrm{mp} 111^{\circ} \mathrm{C}$ [lit. ${ }^{10} 116^{\circ} \mathrm{C}$ ].

$\gamma$-Benzyl-L-glutamyl-L-histidine Methyl Ester Dihydrochloride [L-Glu $(\mathrm{OBzl})$-L-His-OMe $\cdot 2 \mathrm{HCl}](\mathrm{V})$. A solution of III $(7.07 \mathrm{~g}, 14.5 \mathrm{mmol})$ in $4.7 \mathrm{~mol}$ $\mathrm{dm}^{-3} \mathrm{HCl} /$ dioxane $\left(50 \mathrm{~cm}^{3}\right)$ was allowed to stand for 30 minutes at room temperature, and then the solvent was distilled off. $\mathrm{Et}_{2} \mathrm{O}\left(100 \mathrm{~cm}^{3}\right)$ was added to the residue and the mixture was left overnight at $-15^{\circ} \mathrm{C}$ to solidify the product. The solid obtained was very hygroscopic. Yield $5.96 \mathrm{~g}(89 \%)$.

$N$ - $t$-Butyloxycarbonyl-D-leucyl- $\gamma$-benz $y l$-Lglutamyl-L-histidine Methyl Ester [Boc-D-Leu-L$\mathrm{Glu}(\mathrm{OBzl})$-L-His-OMe] (VI). This was synthesized from IV $(4.67 \mathrm{~g}, 12.9 \mathrm{mmol})$ and $\mathbf{V}(5.96 \mathrm{~g}, 12.9$ mmol) as described for the synthesis of III. The product was obtained as an oil. Yield $9.56 \mathrm{~g}(68 \%)$.

$N$-t-Butyloxycarbonyl-D-leucyl-L-glutamyl-Lhistidine Methyl Ester Monoacetate Hydrate (BocD-Leu-L-Glu-L-His-OMe $\cdot \mathrm{AcOH} \cdot \mathrm{H}_{2} \mathrm{O}$ ) (VII). A solution of VI $(9.56 \mathrm{~g}, 8.77 \mathrm{mmol})$ in $10 \% \mathrm{AcOH} /$ $\mathrm{MeOH}\left(50 \mathrm{~cm}^{3}\right)$ was hydrogenated with Pd-black as a catalyst. After 12 hours, the solution was filtered and the filtrate was evaporated to dryness. AcOEt was added to the oily residue, and the mixture was kept at $-15^{\circ} \mathrm{C}$ to yield a hygroscopic crystal. It was recrystalized from $\mathrm{Me}_{2} \mathrm{CHOH} / \mathrm{AcOEt}$. Yield $4.45 \mathrm{~g}$ $(86 \%)$; mp 112-113 ${ }^{\circ} \mathrm{C}$.

Anal. Calcd for $\mathrm{C}_{23} \mathrm{H}_{37} \mathrm{~N}_{5} \mathrm{O}_{8} \cdot \mathrm{CH}_{3} \mathrm{COOH} \cdot \mathrm{H}_{2} \mathrm{O}$ : C, $50.92 \% ; \mathrm{H}, 7.35 \% ; \mathrm{N}, 11.88 \%$. Found: C,
$50.33 \% ; \mathrm{H}, 7.32 \% ; \mathrm{N}, 11.82 \%$.

$N$ - -Butyloxycarbonyl-D-leucyl-L-glutamyl-Lhistidine Hydrazide (Boc-D-Leu-L-Glu-L-His$\mathrm{NHNH}_{2}$ ) (VIII). A solution of VII $(1.38 \mathrm{~g}, 2.34$ $\mathrm{mmol})$ and $24 \%$ hydrazine hydrate $\left(12 \mathrm{~cm}^{3}\right)$ in $\mathrm{MeOH}\left(30 \mathrm{~cm}^{3}\right)$ was made to stand at room temperature for 3 days. The solution was then evaporated to dryness, and the residue was washed with $\mathrm{Et}_{2} \mathrm{O}$ and solidified. Yield $1.1 \mathrm{~g}(92 \%)$.

D-Leucyl-L-glutamyl-L-histidine Methyl Ester Ditrifluoroacetate (D-Leu-L-Glu-L-His-OMe. $\left.2 \mathrm{CF}_{3} \mathrm{CO}_{2} \mathrm{H}\right)$ (IX). A solution of VII $(1.21 \mathrm{~g}, 2.05$ $\mathrm{mmol})$ in trifluoroacetic acid $\left(3 \mathrm{~cm}^{3}\right)$ was stirred for one hour at room temperature, and then evaporated to dryness. The residue was solidified by the addition of $\mathrm{Et}_{2} \mathrm{O}$. Since the product was very hygroscopic, elemental analysis was not performed. Deblocking of $t$-butyloxycarbonyl group was confirmed by infrared spectroscopy. All the $\mathrm{Et}_{2} \mathrm{O}$ insoluble materials were dissolved in $\mathrm{HCONMe}_{2}$ $\left(8 \mathrm{~cm}^{3}\right)$ and subjected to a condensation reaction with VIII.

$N$-t-Butyloxycarbonyl-(D-leucyl-L-glutamyl-Lhistidyl) ${ }_{2}$ Methyl Ester Trihydrate [Boc-(D-Leu-L$\mathrm{Glu}$-L-His $)_{2}-\mathrm{OMe} \cdot 3 \mathrm{H}_{2} \mathrm{O}$ ] (X). A solution of VIII $(1.1 \mathrm{~g}, 2.15 \mathrm{mmol})$ in $\mathrm{HCONMe}_{2}\left(8 \mathrm{~cm}^{3}\right)$ was mixed with concentrated hydrochloric acid $\left(1.92 \mathrm{~cm}^{3}\right)$ and $2 \mathrm{~N} \mathrm{NaNO}{ }_{2}\left(1.1 \mathrm{~cm}^{3}\right)$ with stirring at $-20^{\circ} \mathrm{C}$. After 30 minutes, the solution was cooled to $-30^{\circ} \mathrm{C}$, and $N$-ethylpiperidine $\left(5.0 \mathrm{~cm}^{3}, 36.4 \mathrm{mmol}\right)$ and a solution of $\mathbf{I X}$ in $\mathrm{HCONMe}_{2}$ were added. The solution was kept at $-5^{\circ} \mathrm{C}$ for 3 days, and then the solvent was distilled off. To the residue, $\mathrm{Me}_{2} \mathrm{CO}$ and $\mathrm{EtOH}$ were added and the insoluble $\mathrm{N}$ ethylpiperidine hydrochloride was filtered off. The filtrate was evaporated to dryness, and an aqueous solution of the residue was eluted for purification through a Sephadex G-15 column $(3.2 \times 60 \mathrm{~cm})$. The initial fraction was collected and freeze-dried. Yield $606 \mathrm{mg}(31 \%)$; mp $138-140^{\circ} \mathrm{C}$.

Anal. Calcd for $\mathrm{C}_{40} \mathrm{H}_{62} \mathrm{~N}_{10} \mathrm{O}_{13} \cdot 3 \mathrm{H}_{2} \mathrm{O}: \mathrm{C}, 50.84 \%$; H, $7.25 \%$;, $14.82 \%$. Found: C, $51.11 \%, \mathrm{H}, 7.09 \%$, $\mathrm{N}, 14.45 \%$.

$N$-t-Butyloxycarbonyl-(D-leucyl-L-glutamylL-histidyl) ${ }_{2}$ Hydrazide [Boc-(D-Leu-L-Glu-L-His) ${ }_{2}-$ $\mathrm{NHNH}_{2}$ ] (XI). In a manner similar to the synthesis of VIII, X $(4.28 \mathrm{mg}, 0.45 \mathrm{mmol})$ was treated with hydrazine hydrate $\left(5 \mathrm{~cm}^{3}\right)$. The product was solidified by adding $\mathrm{Me}_{2} \mathrm{CO}$. Yield $361 \mathrm{mg}(90 \%)$.

Cyclo(D-leucyl-L-glutamyl-L-histidyl) ${ }_{2}$ Dihydro- 
chloride 3.5 Hydrate [cyclo(D-Leu-L-Glu-L-His) ${ }_{2}$. $2 \mathrm{HCl} \cdot 3.5 \mathrm{H}_{2} \mathrm{O}$ ] (XII). A solution of XI $(361 \mathrm{mg}$, $0.405 \mathrm{mmol}$ ) in $0.1 \mathrm{~mol} \mathrm{dm}^{-3} \mathrm{HCl} / \mathrm{HCOOH}$ was stirred for one hour at room temperature. The solvent was distilled off and the residue was washed with $\mathrm{Et}_{2} \mathrm{O}$. The product was dissolved in $\mathrm{HCONMe}_{2}\left(20 \mathrm{~cm}^{3}\right)$ and the solution was stirred at $-20^{\circ} \mathrm{C}$. To the solution, $\mathrm{AcOH}\left(1 \mathrm{~cm}^{3}\right)$, concentrated hydrochloric acid $\left(0.2 \mathrm{~cm}^{3}\right)$, and $2 \mathrm{~mol}$ $\mathrm{dm}^{-3}$ aqueous $\mathrm{NaNO}_{2}$ solution $\left(2 \mathrm{~cm}^{3}\right)$ were added. After 15 minutes, the solution was poured into pyridine $\left(200 \mathrm{~cm}^{3}\right)$ at $-5^{\circ} \mathrm{C}$. After being kept at $-5^{\circ} \mathrm{C}$ for 2 days, the solution was evaporated to dryness, and the reaction product was eluted for purification through a column as in the case of $\mathbf{X}$. The product was recrystallized from $\mathrm{Me}_{2} \mathrm{CO} / \mathrm{H}_{2} \mathrm{O}$. Yield $84 \mathrm{mg}(23 \%) ; \mathrm{mp} 196-200^{\circ} \mathrm{C}$. The $R_{f}$ of the material subjected to TLC in $n$-butanol/acetic acid/ water/pyridine $(15: 10: 12: 13)$ was 0.52 .

Anal. Calcd for $\mathrm{C}_{34} \mathrm{H}_{50} \mathrm{~N}_{10} \mathrm{O}_{10} \cdot 2 \mathrm{HCl} \cdot 3.5 \mathrm{H}_{2} \mathrm{O}: \mathrm{C}$, $45.64 \%$; H, $6.42 \%$; N, $15.65 \%$. Found: C, $45.65 \%$; $\mathrm{H}, 6.48 \%$; N $15.79 \%$.

A protected linear tripeptide VII was used as the catalyst for a comparison with the cyclic hexapeptide.

As a standard nucleophile, imidazole was used and compared with the peptide catalysts synthesized. Commercial imidazole was recrystallized from benzene.

\section{Substrates}

As neutral $p$-nitrophenyl esters of carboxylic acids, $\mathrm{CH}_{3} \mathrm{COOPh}\left(\mathrm{NO}_{2}\right),{ }^{1} \quad \mathrm{CH}_{3}\left(\mathrm{CH}_{2}\right)_{8} \mathrm{COOPh}-$ $\left(\mathrm{NO}_{2}\right),{ }^{2}$ and $\mathrm{CH}_{3}\left(\mathrm{CH}_{2}\right)_{10} \mathrm{COOPh}\left(\mathrm{NO}_{2}\right)^{1}$ were used. Syntheses and purifications of these materials have already been described.

As $p$-nitrophenyl ester hydrochlorides of $\alpha$ - and $\omega$-aminocarboxylic acid, which carry a positive charge at the end of the acyl chain, Gly$\mathrm{OPh}\left(\mathrm{NO}_{2}\right) \cdot \mathrm{HCl}$ and $\mathrm{Cl}^{-} \mathrm{H}_{3} \mathrm{~N}^{+}\left(\mathrm{CH}_{2}\right)_{11} \mathrm{COOPh}-$ $\left(\mathrm{NO}_{2}\right)$ were used. Syntheses and purifications of these materials have been reported. ${ }^{3}$

As $p$-nitrophenyl ester hydrochlorides of chiral $\alpha$ amino acid, D- and $\mathrm{L}-\mathrm{Val}-\mathrm{OPh}\left(\mathrm{NO}_{2}\right) \cdot \mathrm{HCl}$ and $\mathrm{D}-$ and $\mathrm{L}-\mathrm{Leu}-\mathrm{OPh}\left(\mathrm{NO}_{2}\right) \cdot \mathrm{HCl}$ were used. Syntheses and purifications of these materials have been reported. ${ }^{3}$

\section{Hydrolytic Reaction}

A solution of neutral p-nitrophenyl ester of car- boxylic acid in dioxane was added to a mixture of an aqueous solution of catalyst and a buffer solution to start the hydrolysis.

A stock solution of $\mathrm{Cl}^{-} \mathrm{H}_{3} \mathrm{~N}^{+}\left(\mathrm{CH}_{2}\right)_{11^{-}}$$\mathrm{COOPh}\left(\mathrm{NO}_{2}\right)$ in $0.01 \mathrm{~mol} \mathrm{dm}{ }^{-3}$ hydrochloric acid containing a small amount of $\mathrm{MeOH}$ was mixed with an aqueous solution of catalyst and a buffer solution to start the hydrolysis.

A stock solution of $\alpha$-amino acid $p$-nitrophenyl ester in $0.01 \mathrm{~mol} \mathrm{dm}^{-3}$ hydrochloric acid was mixed with an aqueous solution of catalyst and a buffer solution to start the hydrolysis.

The concentration of phenolate ion liberated during the hydrolytic reaction was determined by the optical density of $400 \mathrm{~nm}$ absorption. This determination was carried out using a JASCO UVIDEC-1 spectrophotometer. Optical cells having path lengths of $5 \mathrm{~cm}$ and $1 \mathrm{~cm}$ were used, respectively, when the substrate concentrations were $6.0 \times 10^{-6} \mathrm{~mol} \mathrm{dm}^{-3}$ and higher than $3.0 \times 10^{-5}$ mol dm${ }^{-3}$. The second-order rate constant $k_{\text {cat }}$ was determined as reported previously. ${ }^{1}$

\section{Determination of $p K_{\mathrm{a}}$ of Catalyst}

$270 \mathrm{MHz}{ }^{1} \mathrm{H}$ NMR spectra of $\mathrm{D}_{2} \mathrm{O}$ solution of cyclo(D-Leu-L-Glu-L-His) ${ }_{2}$ were measured at $23^{\circ} \mathrm{C}$ with Bruker WH270 spectrometer using $\mathrm{Me}_{3} \mathrm{Si}$ $\left(\mathrm{CH}_{2}\right)_{3} \mathrm{SO}_{3} \mathrm{Na}$ as an internal standard. $\mathrm{p} K_{\mathrm{a}}$ of the Glu-COOH group was determined from the chemical shift change in the Glu-C ${ }^{\gamma} \mathrm{H}_{2}$ signal with $\mathrm{pD}$. $\mathrm{p} K_{\mathrm{a}}$ of the His-imidazolyl-group was determined from the chemical shift change in the imidazolyl$\mathrm{C}^{2} \mathrm{H}$ signal with $\mathrm{pD}$.

\section{RESULTS AND DISCUSSION}

\section{Determination of the $p K_{\mathrm{a}}$ of Cyclic Hexapeptide}

From the pD dependence of the $270 \mathrm{MHz}{ }^{1} \mathrm{H}$ NMR spectrum of a $\mathrm{D}_{2} \mathrm{O}$ solution of cyclo(D-LeuL-Glu-L-His) $)_{2}, \mathrm{p} K_{\mathrm{a}}$ of Glu-COOH was determined to be $4.30 . \mathrm{p} K_{\mathrm{a}}$ of the $\gamma-\mathrm{COOH}$ group of glutamic acid is-4.07 and that of Glu-COOH in cyclo(L-GluL-His) has been reported to be $4.4 .^{5}$ These values are not particularly different from each other and therefore indicate the absence of specific interactions of carboxyl groups in cyclo(D-Leu-L-Glu-L-His) ${ }_{2}$.

As will be reported in the next paper, ${ }^{11}$ cyclo(DLeu-L-Glu-L-His) $)_{2}$ takes several conformations in $\mathrm{D}_{2} \mathrm{O}$ and four signals of imidazolyl- $\mathrm{C}^{2} \mathrm{H}$ appear. From the $\mathrm{pD}$ dependence of each signal, the $\mathrm{p} K_{\mathrm{a}}$ 
values of the His-imidazoyl groups involved in major conformations were determined to be in the range of $6.5-6.85$ and those involved in minor conformations in the range of 7.3-7.5. Allowing for $\mathrm{p} K_{\mathrm{a}}$ of the His-imidazolyl group in cyclo(L-GluL-His) being $6.6,{ }^{5}$ those for minor conformations are much higher than usual. In the minor conformations, there may possibly be some side chain interactions or conformational change at about $\mathrm{pD}$ 6.5 causing an increase in the $\mathrm{p} K_{\mathrm{a}}$ of the Hisimidazoyl group.

The CD spectra of aqueous solution of cyclo(DLeu-L-Glu-L-His) $)_{2}$ were measured at $\mathrm{pH} 4.0,7.0$, and 10.0 , but no serious change in the spectrum was observed. This indicates that no change in the major conformation took place during the $\mathrm{pH}$ titration.

\section{Hydrolysis of Neutral p-Nitrophenyl Esters of Carboxylic Acids}

Since hydrophobic Leu and nucleophilic His residues take a D-L sequence in cyclo(D-Leu-L-Glu-L$\mathrm{His})_{2}$, the cyclic hexapeptide should be an efficient catalyst for the hydrolysis of hydrophobic carboxylic acid esters. ${ }^{1,2}$ Hydrolyses of a series of aliphatic carboxylic acid $p$-nitrophenyl esters, $\mathrm{CH}_{3}$ $\left(\mathrm{CH}_{2}\right)_{n-2} \mathrm{COOPh}\left(\mathrm{NO}_{2}\right)(n=2,10,12)$, were carried out in a $20 \%$ dioxane $/ \mathrm{H}_{2} \mathrm{O}$ mixture, and the results are shown in Table I. To avoid any possible association of $\mathrm{CH}_{3}\left(\mathrm{CH}_{2}\right)_{8} \mathrm{COOPh}\left(\mathrm{NO}_{2}\right)$ and $\mathrm{CH}_{3}$ $\left(\mathrm{CH}_{2}\right)_{10} \mathrm{COOPh}\left(\mathrm{NO}_{2}\right)$ in this solvent, ${ }^{2}$ the initial substrate concentration was kept as low as $6.0 \times$ $10^{-6} \mathrm{~mol} \mathrm{dm}^{-3}$. In the hydrolyses with imidazole as the catalyst, with increasing $n$ from 2 to 10 and finally to 12 , the steric hindrance in the nucleophilic catalysis increased and consequently $k_{\text {cat }}$ decreased. However, in the hydrolyses with the linear tripeptide as the catalyst, with increasing chain length of substrate, $k_{\text {cat }}$ increased slightly. This slight acceleration is due to an intramolecular cooperative catalysis in which a nucleophilic attack by the His-imidazolyl group occurs on long-chain substrates having $n=10$ and 12 and bound with a Leu residue of the linear tripeptide by hydrophobic interaction. In hydrolysis with the cyclic hexapeptide, the reaction rates of substrates having $n=10$ and 12 increased very much. For example, in the hydrolysis of $\mathrm{CH}_{3}\left(\mathrm{CH}_{2}\right)_{10} \mathrm{COOPh}\left(\mathrm{NO}_{2}\right) k_{\text {cat }}$ with the cyclic hexapeptide was about 20 times as large as $k_{\text {cat }}$ with imidazole. The cyclic hexapeptide should be more hydrophobic and bind to the substrate
Table I. Second-order rate constant $k_{\text {cat }}$ $\left(\mathrm{dm}^{3} \mathrm{~mol}^{-1} \mathrm{~min}^{-1}\right)$ for the hydrolysis of $\mathrm{CH}_{3}\left(\mathrm{CH}_{2}\right)_{n-2} \mathrm{COOPh}\left(\mathrm{NO}_{2}\right)^{\mathrm{a}}$

\begin{tabular}{lccl}
\hline \multicolumn{1}{c}{ Catalyst } & $n=2^{\mathrm{b}}$ & $n=10^{\mathrm{c}}$ & $n=12^{\mathrm{c}}$ \\
\hline None $\left(k_{w} \times 10^{3}, \mathrm{~min}^{-1}\right)$ & 0.92 & 0.89 & 0.24 \\
Imidazole & 28 & 15 & 1.8 \\
Boc-D-Leu-L-Glu-L-His-OMe & 6.2 & 7.9 & 9.5 \\
Cyclo(D-Leu-L-Glu-L-His) & 5.8 & 46 & 34 \\
\hline
\end{tabular}

a In $20 \%$ dioxane $/ \mathrm{H}_{2} \mathrm{O}$ mixture at $25^{\circ} \mathrm{C}$ and $\mathrm{pH} 7.8$ ( $\mathrm{KH}_{2} \mathrm{PO}_{4} / \mathrm{NaOH}$ buffer).

b In $3 \%$ dioxane $/ \mathrm{H}_{2} \mathrm{O}$ mixture, [Substrate $]_{0}=3.0 \times$ $10^{-5} \mathrm{~mol} \mathrm{dm}^{-3}$.

c $[\text { Substrate }]_{0}=6.0 \times 10^{-6} \mathrm{~mol} \mathrm{dm}^{-3}$.

more strongly than the linear tripeptide.

To investigate the contribution of hydrophobic interaction to the hydrolysis of $\mathrm{CH}_{3}\left(\mathrm{CH}_{2}\right)_{10^{-}}$ $\mathrm{COOPh}\left(\mathrm{NO}_{2}\right)$, hydrolytic reactions were carried out in media of various water/organic solvent compositions. Under the conditions of the initial substrate concentration being $3.0 \times 10^{-5} \mathrm{~mol} \mathrm{dm}^{-3}$,

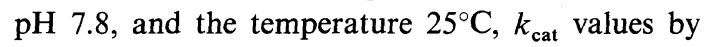
the cyclic hexapeptide and linear tripeptide were nearly zero either in a $33.3 \% \mathrm{EtOH} / 16.7 \%$ dioxane/ $\mathrm{H}_{2} \mathrm{O}$ mixture or in a $50 \%$ dioxane $/ \mathrm{H}_{2} \mathrm{O}$ mixture. It is difficult to explain the change in reactivity in terms of solvent-induced conformational change in the cyclic hexapeptide, since the main-chain conformation of the cyclic hexapeptide without $N$ substituted $\alpha$-amino acid residues should hardly be affected by solvent. Therefore, the above findings indicate that the cyclic hexapeptide is an efficient catalyst only when powerful hydrophobic interaction occurs between the substrate and catalyst in water-rich solvents.

Since two Glu residues and two His residues are present in the cyclic hexapeptide, the latter could be a multifunctional catalyst by intramolecular cooperation of these functional groups. Hydrolyses of $\mathrm{CH}_{3} \mathrm{COOPh}\left(\mathrm{NO}_{2}\right)$ with the cyclic hexapeptide were carried out in a $20 \%$ dioxane $/ \mathrm{H}_{2} \mathrm{O}$ mixture and the $\mathrm{pH}$ dependence of $k_{\text {cat }}$ was examined in a pH range from 4 to 8 . In actuality, the reactions were carried out at $\mathrm{pH} 4.03$ (citrate/ $\mathrm{HCl} / \mathrm{NaOH}$ buffer), $\mathrm{pH} 4.97$ and 6.01 (citrate/ $\mathrm{NaOH}$ buffer), and $\mathrm{pH}$ 6.95 and $7.81\left(\mathrm{KH}_{2} \mathrm{PO}_{4} / \mathrm{NaOH}\right.$ buffer $)$. The results are shown in Figure 2, in which the filled circles represent the observed values and the real line the 
Hydrolytic Catalysis by Cyclo(D-Leu-L-Glu-L-His) ${ }_{2}$

Table III. Second-order rate constant $k_{\text {cat }}\left(\mathrm{dm}^{3} \mathrm{~mol}^{-1} \mathrm{~s}^{-1}\right)$ for the hydrolysis of $\alpha$-amino acid $p$-nitrophenyl ester hydrochloride ${ }^{a}$

\begin{tabular}{|c|c|c|c|c|}
\hline \multirow{2}{*}{ Catalyst } & \multicolumn{2}{|c|}{ Val-OPh $\left(\mathrm{NO}_{2}\right) \cdot \mathrm{HCl}$} & \multicolumn{2}{|c|}{ Leu-OPh$\left(\mathrm{NO}_{2}\right) \cdot \mathrm{HCl}$} \\
\hline & L & $\mathrm{D}$ & $\mathbf{L}$ & D \\
\hline None $\left(k_{w} \times 10^{3}, \mathrm{~s}^{-1}\right)$ & 3.26 & 3.31 & 4.46 & 4.70 \\
\hline Imidazole & 1.2 & 1.2 & 2.1 & 2.0 \\
\hline Boc-D-Leu-L-Glu-L-His-OMe & 0.63 & 0.76 & 0.93 & 0.82 \\
\hline Cyclo(D-Leu-L-Glu-L-His) ${ }_{2}$ & 0.13 & 0.26 & 0.40 & 0.36 \\
\hline
\end{tabular}

a In aqueous solution at $25^{\circ} \mathrm{C}$ and $\mathrm{pH} 6.95\left(\mathrm{KH}_{2} \mathrm{PO}_{4} / \mathrm{NaOH}\right.$ buffer $)$, [Substrate $]_{0}=6.0 \times 10^{-5} \mathrm{~mol} \mathrm{dm}^{-3}$.

Table IV. Second-order rate constant $k_{\text {cat }}\left(\mathrm{dm}^{3} \mathrm{~mol}^{-1} \mathrm{~s}^{-1}\right)$ for the hydrolysis of $\alpha$-amino acid $p$-nitrophenyl ester hydrochloride ${ }^{a}$

\begin{tabular}{llllll}
\hline \multirow{2}{*}{ Catalyst } & \multicolumn{2}{c}{ Val-OPh $\left(\mathrm{NO}_{2}\right) \cdot \mathrm{HCl}$} & & \multicolumn{2}{c}{ Leu-OPh $\left(\mathrm{NO}_{2}\right) \cdot \mathrm{HCl}$} \\
\cline { 2 - 3 } \cline { 5 - 6 } & $\mathrm{L}$ & $\mathrm{D}$ & $\mathrm{L}$ & $\mathrm{D}$ \\
\hline None $\left(k_{w} \times 10^{3}, \mathrm{~s}^{-1}\right)$ & 0.983 & 1.07 & 0.5 & 2.84 & 2.79 \\
Imidazole & 0.8 & 1.4 & 1.1 & 1.1 \\
Boc-D-Leu-L-Glu-L-His-OMe & 2.0 & 0.3 & 2.3 & 2.0 \\
Cyclo(D-Leu-L-Glu-L-His) & 0.3 & & 0.8 & 0.3 \\
\hline
\end{tabular}

${ }^{\text {a }}$ In aqueous solution at $25^{\circ} \mathrm{C}$ and $\mathrm{pH} 6.01$ (citrate buffer), [Substrate $]_{0}=6.0 \times 10^{-5} \mathrm{~mol} \mathrm{dm}^{-3},\left[\mathrm{Cu}(\mathrm{ClO})_{2}\right]=$ $7.0 \times 10^{-4} \mathrm{~mol} \mathrm{dm}^{-3}$.

Table V. Spontaneous rate constant $k_{w}{ }^{\prime}$, pseudo-first-order rate constant $k_{1}$, and second-order rate constant $k_{\text {cat }}$ for the hydrolysis of $\alpha$-amino acid $p$-nitrophenyl ester hydrochloride ${ }^{a}$

\begin{tabular}{lccccc}
\hline & \multicolumn{2}{c}{ Val-OPh $\left(\mathrm{NO}_{2}\right) \cdot \mathrm{HCl}$} & & \multicolumn{2}{c}{$\mathrm{Leu}-\mathrm{OPh}\left(\mathrm{NO} \mathrm{O}_{2}\right) \cdot \mathrm{HCl}$} \\
\cline { 2 - 5 } & $\mathrm{L}$ & $\mathrm{D}$ & $\mathrm{L}$ & $\mathrm{D}$ \\
\hline$k_{w}{ }^{\prime} \times 10^{3}\left(\mathrm{~s}^{-1}\right)^{\mathrm{b}}$ & 1.27 & 1.51 & 1.66 & 1.70 \\
$k_{1} \times 10^{3}\left(\mathrm{~s}^{-1}\right)^{\mathrm{c}}$ & 6.31 & 5.80 & 27.9 & 24.4 \\
$k_{\text {cat }}\left(\mathrm{dm}^{3} \mathrm{~mol}^{-1} \mathrm{~s}^{-1}\right)^{\mathrm{c}}$ & 11.6 & 9.9 & 60.6 & 52.4 \\
\hline
\end{tabular}

a In aqueous solution at $25^{\circ} \mathrm{C}$ and $\mathrm{pH} 6.04\left(\mathrm{KH}_{2} \mathrm{PO}_{4} / \mathrm{NaOH}\right.$ buffer $)$, [Substrate $]_{0}=6.0 \times 10^{-5} \mathrm{~mol} \mathrm{dm}^{-3}$.

b $\left[\mathrm{Cu}\left(\mathrm{ClO}_{4}\right)_{2}\right]=0,\left[\mathrm{Cyclo}(\mathrm{D}-\mathrm{Leu}-\mathrm{L}-\mathrm{Glu}-\mathrm{L}-\mathrm{His})_{2}\right]=0$.

c $\left[\mathrm{Cu}\left(\mathrm{ClO}_{4}\right)_{2}\right]=7.8 \times 10^{-4} \mathrm{~mol} \mathrm{dm}^{-3},\left[\mathrm{Cyclo}(\mathrm{D}-\mathrm{Leu}-\mathrm{L}-\mathrm{Glu}-\mathrm{L}-\mathrm{His})_{2}\right]=4.33 \times 10^{-4} \mathrm{~mol} \mathrm{dm}^{-3}$.

Table IV have not been corrected for effective concentrations of imidazolyl functions. The cyclic hexapeptide was inferior to imidazole under the present conditions. Again, an enantiomer-selective hydrolysis of $\mathrm{Val}-\mathrm{OPh}\left(\mathrm{NO}_{2}\right) \cdot \mathrm{HCl}$ or Leu-OPh$\left(\mathrm{NO}_{2}\right) \cdot \mathrm{HCl}$ was not possible with either of the peptide catalysts.

Added copper ions may interact more strongly with citrate ions as a buffer reagent than the cyclic hexapeptide. Therefore, a weakly interacting phosphate buffer was used in the hydrolysis in the presence of copper ions. Hydrolytic reactions were carried out in aquous solution at $\mathrm{pH} 6.04\left(\mathrm{KH}_{2} \mathrm{PO}_{4} /\right.$ $\mathrm{NaOH}$ buffer) with the addition of $\mathrm{Cu}\left(\mathrm{ClO}_{4}\right)_{2}$. The experimental results are shown in Table V. $k_{w}$ in the presence of $\mathrm{Cu}\left(\mathrm{ClO}_{4}\right)_{2}\left(7.85 \times 10^{-4} \mathrm{~mol} \mathrm{dm}{ }^{-3}\right)$ and 
the absence of cyclic hexapeptide was necessary to determine $k_{\text {cat }}$. However, at pH 6.04 in a phosphatebuffered solution, $\mathrm{Cu}(\mathrm{OH})_{2}$ was precipitated without the cyclic hexapeptide and consequently determination of $k_{w}$ was impossible. We could determine only $k_{w}{ }^{\prime}$, the rate constant for the spontaneous hydrolysis under the absence of copper ions. However, under our conditions the catalysis by copper ions seems not to occur, since the spontaneous hydrolysis of $\alpha$-amino acid ester $\left(k_{w}\right.$ in Table III) was not much different from that in the presence of $\mathrm{Cu}^{2+}\left(k_{w}\right.$ in Table IV), allowing for $\mathrm{pH}$ difference. Therefore, apparent $k_{\text {cat }}$ values were calculted from $k_{1}$ and $k_{w}{ }^{\prime}$ instead of $k_{w}$. The comparison of the apparent $k_{\text {cat }}$ with those in Tables III and IV shows a remarkable increase (up to 150fold increase) of $k_{\text {cat }}$ as a result of the addition of $\mathrm{Cu}^{2+}$ to the phosphate-buffered solution containing the cyclic hexapeptide. In Tables III and IV, it is also seen that Leu-OPh$\left(\mathrm{NO}_{2}\right) \cdot \mathrm{HCl}$ is at most twice as reactive as $\mathrm{Val}-\mathrm{OPh}\left(\mathrm{NO}_{2}\right) \cdot \mathrm{HCl}$ with any hydrolytic catalyst. However, it is shown in Table $\mathrm{V}$ that $\mathrm{Leu}-\mathrm{OPh}\left(\mathrm{NO}_{2}\right) \cdot \mathrm{HCl}$ is almost five times as reactive as $\mathrm{Val}-\mathrm{OPh}\left(\mathrm{NO}_{2}\right) \cdot \mathrm{HCl}$ with the cyclic hexapeptide plus copper ion. These two points indicate that the hydrophobic interaction between the cyclic hexapeptide and the substrate is much more important when copper ions are present than when copper ions are absent. This may be closely related to the conformational change in cyclic hexapeptide induced by copper ions which will be dealt with in the next paper. ${ }^{11}$

In Table $\mathrm{V}$, the apparent $k_{\text {cat }}$ values of $\mathrm{L}$-Val$\mathrm{OPh}\left(\mathrm{NO}_{2}\right) \cdot \mathrm{HCl}$ and $\mathrm{L}-\mathrm{Leu}-\mathrm{OPh}\left(\mathrm{NO}_{2}\right) \cdot \mathrm{HCl}$ are slightly larger than those of the D-enantiomers. Since the catalytic hydrolysis was fast enough to determine the $k_{1}$ values accurately, we believe that the difference in the $k_{\text {cat }}$ values of the L- and Denantiomers is definitely more than the experimental error. With reference to the L-enantiomer selectivity of the cyclic hexapeptide in the presence of copper ions, catalytic hydrolysis by the linear tripeptide under similar conditions should be investigated. However, reproducible rate constants were not obtained in the $\mathrm{pH}$ range $6.0-7.4$. In the $\mathrm{pH}$ range $6.0-7.0$, the precipitation of $\mathrm{Cu}(\mathrm{OH})_{2}$ seriously affected the determination of the reaction rate. In a $\mathrm{pH}$ range above 7 , the precipitation of $\mathrm{Cu}(\mathrm{OH})_{2}$ was less marked but hydrolysis was too fast to be determined accurately by the present method. The order of mixing the buffer solution, the metal salt and the tripeptide has been variously changed, but with no improvement.

In the presence of cyclo(D-Leu-L-Glu-L-His) ${ }_{2}$ $\mathrm{Cu}(\mathrm{OH})_{2}$ did not precipitate from the phosphatebuffered solution, so copper ions must have complexed with the cyclic hexapeptide. The interaction of cyclo(D-Leu-L-Glu-L-His) ${ }_{2}$ with copper ions in a phosphate-buffered solution has been verified by circular dichroism spectroscopy and will be described in the next paper. ${ }^{11}$ The precipitation of $\mathrm{Cu}(\mathrm{OH})_{2}$ in a phosphate-buffered solution containing Boc-D-Leu-L-Glu-L-His-OMe indicates that no interaction occurred. In fact, the circular dichroism spectra of the linear tripeptide in phosphatebuffered solution at $\mathrm{pH} 6.0,7.0$ and 7.8 did not change at all by the addition of $\mathrm{Cu}\left(\mathrm{ClO}_{4}\right)_{2}$. Therefore, the enormous rate increase and slight selectivity of $\mathrm{L}$-enantiomers in the hydrolysis of Val$\mathrm{OPh}\left(\mathrm{NO}_{2}\right) \cdot \mathrm{HCl}$ and Leu-OPh$\left(\mathrm{NO}_{2}\right) \cdot \mathrm{HCl}$ must have come about through the cyclo(D-Leu-L-Glu-LHis) ${ }_{2}-\mathrm{Cu}^{2+}$ complex.

\section{Effects of Metal Ions}

A remarkable increase in reaction rate by the addition of metal ions has been observed in the hydrolysis of 8-acetoxyquinoline-2-carboxylic acid ${ }^{12}$ and in the aminolysis of penicillin..$^{13}$ In these examples, a metal ion coordinates to the substrate and activates it for reaction. However, under our conditions, we found no evidence for the interaction of $\alpha$-amino acid ester hydrochloride with metal ions.

As stated in the previous section, a copper ion is considered to be bound to the cyclic hexapeptide in phosphate-buffered solution. Coordination of metal ions to a multifunctional catalyst and activation of nearby catalytic groups have been reported. ${ }^{14-16}$ Under these conditions, orientation of the substrate seems necessary for acceleration of the reaction. However, no experimental evidences for alignment of functional groups, metal ion, and substrate are presented in these examples. In our cyclic hexapeptide, the two carboxyl groups must be ligand groups bound to a copper ion.

The present cyclic hexapeptide was an efficient catalyst for the hydrolysis of $p$-nitrophenyl esters of neutral, long-chain carboxylic acid, but not very efficient for that of cationically charged, long-chain carboxylic acid. A similar trend was observed with cyclic dipeptide catalysts. ${ }^{3}$ Overberger and 
Podsiadley ${ }^{17}$ reported that copolymers of 5(6)vinylbenzimidazole and acrylic acid accelerated the solvolysis of cationically charged, long-chain carboxylic acid esters because of the contribution of apolar interactions. It was therefore considered ${ }^{3}$ that a hydrophobic domain should be formed about the catalytic site to ensure the occurrence of hydrophobic interactions between a cationically charged substrate and catalyst. The highly efficient catalysis by the cyclo(D-Leu-L-Glu-L-His) ${ }_{2}-\mathrm{Cu}^{2+}$ complex in the hydrolysis of cationically charged $\alpha$-amino acid ester hydrochlorides should, therefore, indicate the formation of a hydrophobic domain by coordination of copper ion. Further investigation is necessary to confirm this consideration, whether the cyclic hexapeptide is an efficient catalyst for $\mathrm{CH}_{3}\left(\mathrm{CH}_{2}\right)_{10} \mathrm{COOPh}\left(\mathrm{NO}_{2}\right)$, $\mathrm{CH}_{3}\left(\mathrm{CH}_{2}\right)_{8} \mathrm{COOPh}\left(\mathrm{NO}_{2}\right)$, and $\mathrm{Cl}^{-} \mathrm{H}_{3} \mathrm{~N}^{+}\left(\mathrm{CH}_{2}\right)_{11^{-}}$ $\mathrm{COOPh}\left(\mathrm{NO}_{2}\right)$ in the presence of copper ions.

The cyclo(D-Leu-L-Glu-L-His) ${ }_{2}-\mathrm{Cu}^{2+}$ complex may be the first example showing that a cyclic peptide is an enantiomer-selective catalyst of ester hydrolysis, although the difference in the reaction rates of the L- and D-enantiomers was not very large. The enantiomer-selective hydrolysis of phenylalanine esters with poly(L-lysine)- $\mathrm{Cu}^{2+}$ complex has been reported by Hatano, et al. ${ }^{18,19}$ In these examples, the copper ion is a catalyst and the polypeptide only a chiral ligand. Under our conditions, catalysis by copper ions does not seem to occur as described above.

A hydrophobic $\alpha$-amino acid ester hydrochloride should be bound to a hydrophobic domain of cyclo(D-Leu-L-Glu-L-His) ${ }_{2}-\mathrm{Cu}^{2+}$ complex and subjected to intramolecular catalysis by His-imidazolyl groups. Either the substrate binding or the intramolecular catalysis or both should be enantiomer-selective. Since for cyclic peptides conformation can be made clear by sepectroscopy, investigation of the stereochemistry of cyclo(D-Leu-
L-Glu-L-His) $)_{2}-\mathrm{Cu}^{2+}$ complex may provide a clue in elucidating the mechanism of enantiomer-selective hydrolysis. ${ }^{11}$

Acknowledgment. The authors wish to thank Mr. A. Mori of this Department for his assistance with the experimental work.

\section{REFERENCES}

1. Y. Imanishi, M. Tanihara, T. Sugihara, and T. Higashimura, Biopolymers, 16, 2203 (1977).

2. Y. Masuda, M. Tanihara, Y. Imanishi, and T. Higashimura, Biopolymers, submitted.

3. K. Kawaguchi, M. Tanihara, and Y. Imanishi, Polym. J., 15, 97 (1983).

4. M. Tanihara, Y. Imanishi, and T. Higashimura, Biopolymers, 16, 2217 (1977).

5. M. Tanihara and Y. Imanishi, Int. J. Biol. Macromol., 4, 194 (1982).

6. M. Tanihara, Y. Kikuchi, and Y. Imanishi, Int. J. Biol. Macromol., 4, 297 (1982).

7. Y. Kikuchi, M. Tanihara, and Y. Imanishi, Int. J. Biol. Macromol., 4, 305 (1982).

8. K. Nakajima and M. Okamura, Bull. Chem. Soc. Jpn., 46, 1811 (1982).

9. R. L. M. Synge, Biochem. J., 42, 99 (1948).

10. G. W. Anderson, J. E. Zimmerman, and F. M. Callahan, J. Am. Chem. Soc., 86, 1839 (1964).

11. M. Tanihara and Y. Imanishi, Polym. J., 15, 509 (1983).

12. R. W. Hay and C. R. Clark, J. Chem. Soc., Dalton Trans., 1993 (1977).

13. N. P. Gensmantel, E. W. Gowling, and M. I. Page, J. Chem. Soc., Perkin Trans. 2, 335 (1978).

14. T. Takagishi and I. M. Klotz, Biopolymers, 18, 2497 (1979).

15. M. Takeishi, T. Watanabe, S. Niino, and S. Hayama, J. Polym. Sci., Polym. Chem. Ed., 18, 3081 (1980).

16. T. Eiki, S. Kawada, K. Matsushima, M. Mori, and W. Tagaki, Chem. Lett., 997 (1980).

17. C. G. Overberger and C. J. Podsiadly, Bioorg. Chem., 3, 35 (1974).

18. T. Nozawa, Y. Akimoto, and M. Hatano, Makromol. Chem., 158, 21 (1972).

19. T. Nozawa, Y. Akimoto, and M. Hatano, Makromol. Chem., 161, 289 (1972). 